\title{
МАТЕРІАЛОЗНАВСТВО
}

НАЩОНАЛЬНОÏ

АКАДЕМІї НАУК

УКРАЇНИ

https://doi.org/10.15407/dopovidi2020.10.035

удК 612.67:577.24[546.65:66.-911.48]

Yu.V. Nikitchenko ${ }^{1}$, V.K. Klochkov ${ }^{2}$, N.S. Kavok ${ }^{2}$, N.A. Karpenko ${ }^{2}$, O.O. Sedyh $^{2}$, I.V. Nikitchenko ${ }^{1}$, A.I. Bozhkov ${ }^{1}$, S.L. Yefimova $^{2}$, V.P. Seminozhenko ${ }^{2}$

${ }^{1}$ V.N. Karazin Kharkiv National University

2 Institute for Scintillation Materials, SIC "IMK" of the NAS of Ukraine, Kharkiv

E-mail:kavok@isma.kharkov.ua

\section{Cerium oxide nanoparticles and metformin increase the reliability of the prooxidant/antioxidant balance and the survival of ageing rats}

Presented by Academician of the NAS of Ukraine V.P. Seminozhenko

In comparison with the action of metformin - mimetic of the calorie restricted diet, which prolong the animals lifespan, it has been studied the effect of nanoparticles of cerium dioxide $\left(\mathrm{CeO}_{2} \mathrm{NPs}(1-2 \mathrm{~nm})\right.$ ) on survival, physiological indices (the concentration of thyroxine, rectal temperature), as well as biochemical indices (content of lipid hydroperoxides, aconitase, glutathione peroxidase, glutaredoxin, glutathione reductase, NADP+ -dehydrogenase activities (glucose-6-phosphate-, malate- and isocitrate dehydrogenase)) in serum, liver mitochondrial and postmitochondrial fraction of ageing rats.

It has been found that the prolonged use of $\mathrm{CeO}_{2} \mathrm{NPs}$ with drinking water $(0.25-0.30 \mathrm{mg} / \mathrm{kg}$ of body weight per day) and metformin (100-110 mg/ $\mathrm{kg}$ of body weight per day) from 670 days after the birth lead to a significant increase in survival (the median survival of control rats was 900, in animals treated with $\mathrm{CeO}_{2} \mathrm{NPs}-960$, and metformin - 990 days), a decrease in rectal temperature, a slowdown in the decrease in the level of thyroxine in blood, and normalization of the prooxidant/antioxidant balance in liver and blood tissues. Calculated integral index of reliability of prooxidant-antioxidant balance (reliability coefficient) in the studied tissues of rats in response to the application of the $\mathrm{CeO}_{2} \mathrm{NPs}$ increased 4.99 times, and metformin - 4.94 times compared to intact animals. The data obtained allow us concluding about the prospects of the $\mathrm{CeO}_{2} \mathrm{NPs}$, as well as metformin for the development of geroprotector drugs, increasing the healthspan and survival of an ageing organism.

Keywords: $\mathrm{CeO}_{2}$ nanoparticles, metformin, prooxidant/antioxidant balance, thyroxine, body temperature, liver, blood, survival of old male rats.

Ци т у в ан н я: Nikitchenko Yu.V., Klochkov V.K., Kavok N.S., Karpenko N.A., Sedyh O.O., Nikitchenko I.V., Bozhkov A.I., Yefimova S.L., Seminozhenko V.P. Cerium oxide nanoparticles and metformin increase the reliability of the prooxidant/antioxidant balance and the survival of ageing rats. Допов. Нац. акад. наук Укр. 2020. № 10. C. 35-44. https://doi.org/10.15407/dopovidi2020.10.035 
Introduction. It is now known that one of the effective non-genetic models, which lead to a significant increase in life expectancy, is the calorie restriction (CR) [1, 2]. It should be noted that the main mechanism of the effect of CR on the body is a slowdown in the development of oxidative stress [2-5]. At the same time, it was shown that the effectiveness of CR on life expectancy is manifested only when it is used from the early stages of ontogenesis. Therefore, a number of authors believe that the CR cannot currently be used to increase the human lifespan [6]. In this regard, recently, to increase organism`s lifespan, a number of antidiabetic drugs imitating the effect of CR (CR-mimetics) are being considered. These drugs include biguanides (phenformin, buformin, metformin), which also exhibit antioxidant properties [7]. Currently, there is evidence that these drugs increase the life span of nematodes, mice, and rats [7]. At the same time, there is evidence of the absence of the effect of biguanides on the lifespan of animals [8]. Moreover, detected slight toxicity of metformin requires additional methods of correction during its long-term use [9].

Therefore, the search for new antioxidant drugs capable of increasing the lifespan is relevant. Of particular interest are the NPs of dioxide cerium $\left(\mathrm{CeO}_{2} \mathrm{NPs}\right)$ which show SOD- and catalase-like activity, preventing oxidative damage and increase survival of mice with impaired SOD activity [10].

The aim of this work is to study the effect of $\mathrm{CeO}_{2} \mathrm{NPs}$, and metformin on the state of the prooxidant/antioxidant balance and the survival rate of ageing rats.

Materials and Methods. Aqueous solutions of $\mathrm{CeO}_{2} \mathrm{NPs}$ were obtained by the following method [11]: $100 \mathrm{ml}$ of a solution of $\mathrm{CeCl}_{3}(0.002 \mathrm{~mol} / \mathrm{L})$ were mixed with $100 \mathrm{ml}$ of a solution of hexamethylenetetramine $(0.004 \mathrm{~mol} / \mathrm{L})$ and stirred by using a magnetic stirrer for $3 \mathrm{~h}$ at room temperature. After that, $1.8 \mathrm{ml} \mathrm{NH}_{4} \mathrm{OH}$ and $0.6 \mathrm{ml}$ of $\mathrm{H}_{2} \mathrm{O}_{2}$ were added into the solution. Then the solution was put in round-bottom flask and was refluxed for $5 \mathrm{~h}$. As a result, transparent colorless solutions were obtained. The solution was evaporated in a rotary evaporator flask under vacuum at the bath temperature of $70^{\circ} \mathrm{C}$ to $30 \mathrm{ml}$. A solution of $1 \mathrm{M} \mathrm{CaCl}_{2}$ was added to the obtained solution until the resulting solution became turbid. Then coagulated ceria nanoparticles were isolated by centrifugation and redispersed in a solution of $1 \mathrm{M} \mathrm{CaCl}_{2}$ again. The procedure of precipitate cleaning was repeated three times. After the last stage of centrifugation, a solution of sodium citrate with a molar ratio $\mathrm{CeO}_{2} / \mathrm{NaCt}$ of 1: 1 was added to the precipitate. The solutions were additionally dialyzed for $24 \mathrm{~h}$ against deionized water to remove the excess of ions and organics species. Dialysis membrane tubing with a molecular weight cutoff of "Cellu Sep H1" $3.5 \mathrm{KDa}$ was used, and water was renewed each $6 \mathrm{~h}$ (the water / colloid volume ratio is 40). Thus, the impurity-free solution was found to be transparent in transmitted light at a concentration $\mathrm{CeO}_{2}$ of $1 \mathrm{~g} / \mathrm{L}$ with a poorly yellow color. As evident from Fig. 1, the particles are spherical and well-dispersed with the average particle size of about $2 \mathrm{~nm}$.

Investigations were performed on male Wistar rats maintained under standard vivarium conditions in accordance with the guidelines of the European Convention for the Protection of the Vertebrata using for the Experimental and Scientific Purposes (1986). In the experiment, 12 months old (6 rats) and 23 months old animals (61 rats) were used. The manipulations with the animals were carried out in accordance with the European Convention for the Protection of Vertebrate Animals used for Experimental and Scientific Purposes (Strasbourg, 1986). 
$\mathrm{CeO}_{2}$ NPs were given to the experimental 23months rats (31 individual) with drinking water at a final dose of $0.25-0.3 \mathrm{mg} / \mathrm{kg}$ body weight per day for the end of life, metformin was given with drinking water at a final dose at 100-110 $\mathrm{mg} / \mathrm{kg}$ body weight [8]. Animals that received standard drinking water and were kept under the same conditions constituted the Control group (30 animals). Rectal temperature measurements were performed using ThermoWorks Microtherma $2 \mathrm{~T}$ (USA). The concentration of thyroxine $\left(\mathrm{T}_{4}\right)$ was determined by the enzyme immunoassay using the Total $\mathrm{T}_{4}$ RIA kit from IMMUNOTECH (Czech Republic).

At the age of 33-month- old, 6 animals from each group were scarified, and the state of prooxidant/antioxidant balance was investigated. Mitochondrial

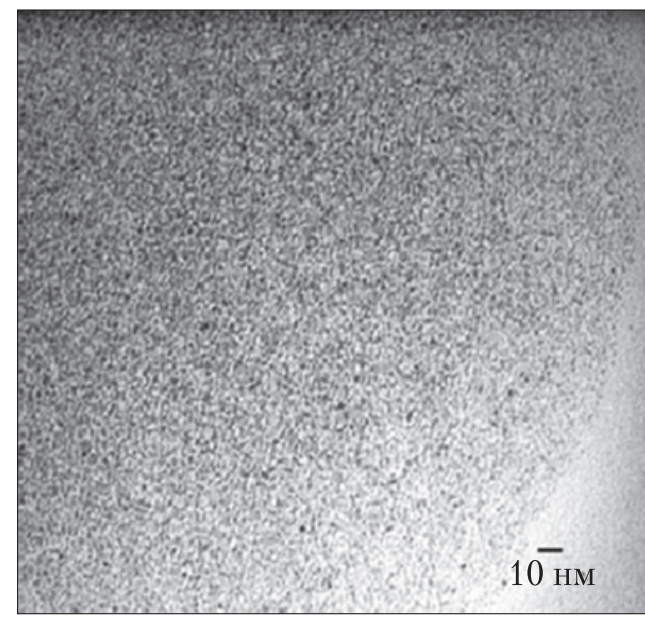

Fig. 1. TEM image of synthesized $\mathrm{CeO}_{2} \mathrm{NPs}$ (MC), postmitochondrial (PMC) fractions of liver were obtained by differential centrifugation immediately after necropsy. These samples, as well as serum (S), were either analyzed immediately (lipid hydroperoxide, LHPO) or stored in liquid nitrogen till the analysis.

The parameters of the prooxidant/antioxidant balance were measured using the methods described by us earlier $[4,5,12]$. LHPO content in liver was determined by the method of Ohkawa et al. (1979), and in serum - by the method of Asakawa et al. (1980) spectrophotometrially (UV VIS, Germany). Aconitase activity (Aco) (EC 4.2.1.3) was determined in MC with spectrophotometry at $240 \mathrm{~nm}$, as described by Varghese (2003) with minor changes. Glutathione peroxidase (GPx) activity in liver fractions was measured in a reaction coupled with exogenous glutathione reductase spectrophotometrially at $340 \mathrm{~nm}$ by the method of Paglia and Valentine (1967). Determination of glutaredoxin activity (Grx) (EC 1.20.4.1) in liver MC was measured with spectrophotometry at $340 \mathrm{~nm}$ (Gallogly et al. 2010) Glutathione reductase (GR) activity in $\mathrm{MC}$ and PMC was determined by oxidation of NADPH spectrophotometry at $340 \mathrm{~nm}$ according to the method of Carlberg (1975). Glucose-6-phosphate dehydrogenase (G-6-PDG) activity, NADP-dependent isocitrate dehydrogenase (ICDG) activity, and NADP-dependent malate dehydrogenase (MDG) activity were investigated by the restoration of $\mathrm{NADP}^{+}$according to the methods of Zaheer (1967), Bauman (1970), Usatenko (1974). Protein content was determined by the Lowry method in the modification by Miller (1959).

The integral index of the prooxidant/antioxidant balance in liver mitochondria of young and old animals as reliability coefficient $(\mathrm{K} r)$ was calculated using the formula [12]:

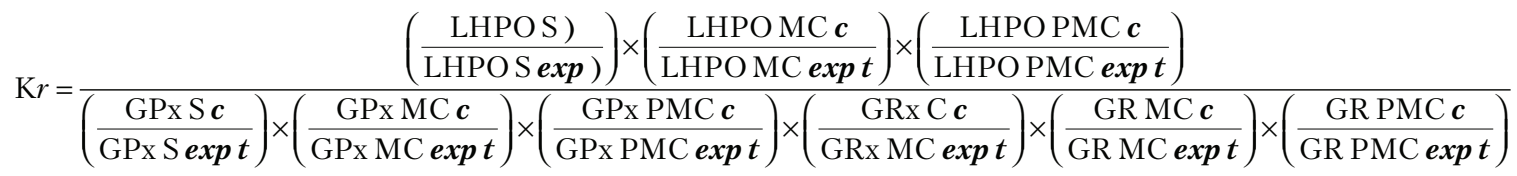

where the values with the indices $\exp \boldsymbol{t}$ correspond to the ones obtained for animals treated with $\mathrm{NPs} \mathrm{CeO}_{2}$, and the values with the indices $\boldsymbol{c}$ - to control rats. The values in the formula are taken from tables 1 and 2 of the present work. 
The obtained results were processed with the Student's $t$-test using the "Statistica v.6" computer software package. Analysis for survival was performed using the Kaplan-Meyer test. Survival curves were compared using the Gehan method with Yates correction. All data were expressed as mean \pm SEM. Significance level was set at $p<0.05$.

Results and Discussion. From the literature, it is known that an experimental decrease in body temperature of animals can lead to an increase in life expectancy [13]. In particular, it has been shown that the long-term use of a calorie-limited life-prolonging diet is accompanied by a decrease in rectal temperature in experimental mice and rats. Also shown is a decrease in rectal temperature in experimental animals with the long-term use of biguanides (phenformin, buformin, metformin), which increase life expectancy [7].

In our studies, we have found that $\mathrm{CeO}_{2}$ NPs or metformin applications within 100-110 days significantly reduce rectal temperature compared to control animals. So, in particular, when using $\mathrm{CeO}_{2} \mathrm{NPs}$, the rectal temperature decreased by $0.58^{\circ} \mathrm{C}$ and when using metformin - by $0.78{ }^{\circ} \mathrm{C}$ $(p<0.05 ; n=24-31)$.

In this regard, it can be concluded that $\mathrm{CeO}_{2}$ NPs affect rectal temperature in very old animals in the same way as metformin (CR-mimetic) and just like the calorie-restricted life-prolonging diet itself.

Important indicator, which characterizes the rate of ageing, can be the level of thyroid hormones in the blood. Numerous data indicate that the content of thyroid hormones decreases significantly with the age of mammals [13].

In our studies, it is found that thyroxine $\left(T_{4}\right)$ content in 32-month-old (975 days after birth) control rats is significantly, by $27.2 \%$, lower as compared with the level of hormone in adults 12-months (365 days after birthday) control animals. Prolonged use of $\mathrm{CeO}_{2}$ NPs significantly slowed a decrease in the concentration of this hormone in blood serum. Thus, in 32-month-old experimental rats, the $T_{4}$ level does not significantly differ from this indicator in 12-month-old control animals (data not shown).

A significant slowdown in the decrease in serum $T_{4}$ in very old, 32-month-old rats is also found with a long-term use of metformin. In this regard, it should be noted that the deceleration in reduction of blood $T_{4}$ concentrations is characteristic of the action of $\mathrm{CR}$, which prolongs the lifespan of animals $[4,5]$. Thus, it can be concluded that the $\mathrm{NPs}_{\mathrm{CeO}}$ slow the age-dependent declining of $T_{4}$ level as a CR-mimetic - metformin and just the CR.

It has been shown that, at the late stages of ontogenesis in rats, during natural ageing, the content of products of free radical oxidation of biomolecules in liver and blood significantly increases, and the activity of a number of antioxidant enzymes decreases [5]. Therefore, it was of interest to investigate the prooxidant/antioxidant balance in liver and blood of experimental animals at the long-last use of $\mathrm{CeO}_{2} \mathrm{NPs}$ or metformin. It has been shown that, in very old 32-month-old control rats, LHPO content in blood serum, liver PMC and MC fractions was by $23.5 \%, 28.0 \%$ and $36.2 \%$ higher, than in 12-months control animals (Table 1 ).

In response to the $\mathrm{CeO}_{2}$ NPs application, the level LHPO in serum, liver PMC and MC of 32-month-old animals is significantly reduced as compared to the control values and leveled with ones in the tissues of 12-month-old rats (Table 1). Similar changes of lipid peroxidation products in serum, liver MC and PMC of experimental animals are detected in response to the long-term use of metformin (see Table 1). In this connection, it should be noted that the de- 
celeration of the LHPO accumulation have been identified earlier in the study of long-last use of CR, which prolongs the life of animals [4,5].

Another indicator of the state of the prooxidant potential is the value of aconitase activity (Aco) in liver mitochondria. Aco is the only enzyme in the liver MC which activity is considerably reduced, proportionally to oxidative stress intensity and ageing. Our studies reveal that, in old control rats (32 months old), Aco activity is reliably lower than in adults 12 months animals (see Table 1). In experimental old rats, which received $\mathrm{CeO}_{2} \mathrm{NPs}$, this activity remains at the level of adult 12-months rats. Similar changes of Aco activity are also observed at the prolonged administration of metform.

Thus, the data obtained indicate that the long-term use of $\mathrm{CeO}_{2}$ NPs maintains the prooxidant potential of liver and blood of 32-month-old experimental animals at the reduced level of adult 12-month-old control rats. A decrease in the prooxidant potential of very old 32-monthold rats also occurred with long-term use of metformin.

The content of LHPO in body tissues is controlled mainly by the glutathione peroxidase antioxidant system (glutathione peroxidase, a number of isoenzymes of glutathione- S- transferase and glutaredoxin). In our earlier studies, it was found that, at the later stages of ontogenesis, the activity of glutathione peroxidase (GPx) in the liver and blood significantly decreases [5].

In the present work, we have shown a decrease in the GPx activity in serum, liver PMC and MC in 32-months control rats to $19.1 \%, 20.3 \%$, and $25.8 \%$, respectively, as compared to the activity in 12-month-old control animals $(p<0.05$, Table 1$)$. Prolonged use of $\mathrm{CeO}_{2} \mathrm{NPs}_{\text {signi- }}$ ficantly retards the lowering of GPx activity. The use of metformin also resulted in a significant reduction in a deceleration of the GPx activity in serum, liver PMC and MC of 32-months experimental animals (Table 1). In this connection, it should be noted that a slowdown of a decrease in the GPx activity in liver and blood was also revealed by us in response to CR [4, 5].

Table 1. Lipid hydroperoxides content and activities of aconitase, glutathione peroxidase, and glutaredoxin in liver and blood

of ageing rats received nanoparticles $\mathrm{CeO}_{2}$ or metformin $(n=6)$

\begin{tabular}{|c|c|c|c|c|c|}
\hline \multirow{2}{*}{ Parameter } & \multirow{2}{*}{$\begin{array}{l}\text { Tissue/ } \\
\text { Liver } \\
\text { fraction }\end{array}$} & 12-months & \multicolumn{3}{|c|}{ 32-months } \\
\hline & & Control & Control & $\mathrm{CeO}_{2} \mathrm{NPs}$ & Metformin \\
\hline LHPO nmol MDA / ml & Serum & $2.51 \pm 0.09$ & $3.10 \pm 0.12^{*}$ & $2.36 \pm 0.09^{* *}$ & $2.39^{* *} \pm 0.06^{* *}$ \\
\hline LHPO, nmol MDA / mg & PMC & $0.250 \pm 0.012$ & $0.320 \pm 0.070^{*}$ & $0.242 \pm 0.012^{* *}$ & $0.246 \pm 0.009 * *$ \\
\hline protein & $\mathrm{MC}$ & $0.403 \pm 0.025$ & $0.549 \pm 0.045^{*}$ & $0.422 \pm 0.031^{* *}$ & $0.373 \pm 0.027 * *$ \\
\hline $\begin{array}{l}\text { Aco, nmol aconitate } / \mathrm{min} \cdot \mathrm{mg} \\
\text { protein }\end{array}$ & $\mathrm{MC}$ & $31.0 \pm 8.0$ & $24.9 \pm 0.8^{*}$ & $29.9 \pm 1.0^{* *}$ & $29.7 \pm 1.7^{* *}$ \\
\hline $\mathrm{GPx}, \mu \mathrm{mol} \mathrm{NADPH} / \mathrm{min} \cdot \mathrm{ml}$ & Serum & $5.77 \pm 0.27$ & $4.67 \pm 0.12^{*}$ & $5.34 \pm 0.30$ & $5.69 \pm 0.38^{* *}$ \\
\hline GPx, nmol NADPH / min $\cdot \mathrm{mg}$ & PMC & $604.4 \pm 29.4$ & $481.7 \pm 27.4^{*}$ & $623.5 \pm 55.6$ & $606.5 \pm 44.0$ \\
\hline protein & $\mathrm{MC}$ & $394.5 \pm 31.0$ & $292.9 \pm 21.7^{*}$ & $352.7 \pm 18.3$ & $330.9 \pm 14.7$ \\
\hline $\begin{array}{l}\text { Grx, nmol NADPH / min } \cdot \mathrm{mg} \\
\text { protein }\end{array}$ & $\mathrm{MC}$ & $4.31 \pm 0.19$ & $3.46^{*} \pm 0.22$ & $4.27 \pm 0.27$ & $4,00 \pm 0.13$ \\
\hline
\end{tabular}

Notes: ${ }^{*}-p<0.05$ compared with control 12 -months animals; ${ }^{* *}-p<0.05$ in comparison with the control 32-months animals 
The study of another enzyme, utilizing lipid hydroperoxides and hydrogen peroxide - glutaredoxin (Grx), shows that the enzyme activity in old control rats is significantly lower than the activity in 12-months control animals. Prolonged use of $\mathrm{CeO}_{2} \mathrm{NPs}$ and metformin prevents a decline of the Grx activity (Table 1).

Investigation of the activity of glutathione reductase (GR), an enzyme that provides GPx and Grx with reduced glutathione reveals no significant changes in this activity in the liver $\mathrm{MC}$ of control animals ,as well as of rats long-last receiving $\mathrm{CeO}_{2} \mathrm{NPs}$ and metformin (Table 2).

In the study of enzyme activities providing mitochondrial GR with reduced NADPH NADP-dehydrogenases (G-6-PDG, MDH and ICDG), significant changes in 32-month-old control animals compared to the controls 12 -months are not detected (Table 2). In experimental animals, only a tendency to increase the G-6-PDG activity in response to the prolonged use of $\mathrm{CeO}_{2}$ NPs is observed.

When studying the activity of the same enzymes in the liver PMC, it has been found that the GR activity in control 32-month old rats is significantly lower than in adult 12 months of age (Table 2). These data are consistent with our earlier results, which indicate a decrease in the GR activity in rat liver PMC with ageing [5].

Long-term use of $\mathrm{CeO}_{2} \mathrm{NPs}$ significantly slows down the decrease in the studied activity in the PMC of the liver fraction. A similar effect on the GR activity of the liver PMC was found with a long-term use of metformin (Table 2).

The study of the NADP-dependent dehydrogenases activity in the liver PMC established that only the ICDH activity decreases significantly in 32-month-old control rats (as compared to the 12-month control animals) (Table 2). The prolonged use of $\mathrm{CeO}_{2} \mathrm{NPs}_{\text {significantly retards }}$ the reduction of the activity. A significant slowdown in the decrease in the ICDH activity in the liver PMC was also found with a long-term use of metformin.

G-6-PDG activity in the liver PMC of control 32-month-old rats practically does not differ from the activity of 12-month-old control animals. With prolonged use of $\mathrm{CeO}_{2} \mathrm{NPs}$, the stud-

Table 2. Glutathione- and NADP-reductase activities in liver mitochondrial and postmitochondrial fractions of rats at the prolonged use of $\mathrm{CeO}_{2}$ nanoparticles or metformin $(n=6)$

\begin{tabular}{|c|c|c|c|c|c|}
\hline \multirow{2}{*}{ Parameter } & \multirow{2}{*}{$\begin{array}{l}\text { Liver } \\
\text { fraction }\end{array}$} & \multirow{2}{*}{$\begin{array}{c}\text { 12- months } \\
\text { Control } \\
\end{array}$} & \multicolumn{3}{|c|}{ 32-months } \\
\hline & & & Control & $\mathrm{CeO}_{2}$ NPs & Metformin \\
\hline \multirow{2}{*}{$\begin{array}{l}\mathrm{GR}, \mathrm{nmol} \mathrm{NADPH} / \\
\mathrm{min} \cdot \mathrm{mg} \text { protein }\end{array}$} & $\mathrm{MC}$ & $40.3 \pm 3.4$ & $34.1 \pm 2.0$ & $36.4 \pm 2.6$ & $38.5 \pm 2.0$ \\
\hline & PMC & $52.3 \pm 3.7$ & $43.1 \pm 1.3^{*}$ & $60.0 \pm 7.2 * *$ & $54.1 \pm 4.4^{* *}$ \\
\hline \multirow{2}{*}{$\begin{array}{l}\mathrm{ICDH}, \mathrm{nmol} \mathrm{NADPH} / \\
\mathrm{min} \cdot \mathrm{mg} \text { protein }\end{array}$} & $\mathrm{MC}$ & $247.9 \pm 16.1$ & $206.9 \pm 31.9$ & $243.2 \pm 18.9$ & $235.0 \pm 30.0$ \\
\hline & PMC & $304.4 \pm 19.7$ & $233.7 \pm 10.0^{*}$ & $314.8 \pm 34.6^{* *}$ & $288.4 \pm 13.2^{* *}$ \\
\hline \multirow{2}{*}{$\begin{array}{l}\text { G- } 6-\mathrm{PDG}, \text { nmol NADPH / } \\
\mathrm{min} \cdot \mathrm{mg} \text { protein }\end{array}$} & $\mathrm{MC}$ & $23.0 \pm 1.4$ & $20.1 \pm 2.6$ & $27.2 \pm 2.5 \bullet$ & $22.9 \pm 3.2$ \\
\hline & PMC & $52.1 \pm 5.8$ & $49.6 \pm 6.5$ & $115.2 \pm 17.3^{*, * *}$ & $93.6 \pm 23.0 \bullet$ \\
\hline \multirow{2}{*}{$\begin{array}{l}\mathrm{MDH}, \mathrm{nmol} \mathrm{NADPH} / \\
\mathrm{min} \cdot \mathrm{mg} \text { protein }\end{array}$} & $\mathrm{MC}$ & $4.38 \pm 0.45$ & $3.32 \pm 0.44$ & $3.29 \pm 0.42$ & $3.44 \pm 0.35$ \\
\hline & PMC & $37.9 \pm 4.8$ & $30.2 \pm 4.5$ & $45.9 \pm 3.6^{* *}$ & $28.9 \pm 3.3$ \\
\hline
\end{tabular}

Notes: $*-p<0.05$ compared to the control of 12-month-old animals; ${ }^{*}-p<0.05$ compared to the control of 32-month-old animals; $\bullet-0.05<p<0.1$ in comparison with the control 32-months animals 
ied activity is significantly increased (by $121.1 \%$ compared to control 12-months animals and by $132.3 \%$ in comparison with the control 32 -months rats). In this connection, it should be noted that, in the liver $\mathrm{MC}$ of rats received $\mathrm{CeO}_{2}$ NPs, the G-6-PDG activity is somewhat higher (by $35.3 \%$ ) than in the control 32-month old animals (Table 2).

In the case of prolonged use of metformin, G-6-PDG activity increases less remarkably than at the $\mathrm{CeO}_{2}$ NPs use.

When studying the activity of NADP- dependent MDH in the PMC of the liver, it has been found that, in old 32-month-old rats, the studied activity is slightly lower (by $20.3 \%$ ) than in control 12-month-old animals (Table 2). Long-term use of $\mathrm{CeO}_{2}$ NPs increases the activity by $52.0 \%$ in comparison with the old control animals. At the same time, long-term use of metformin did not significantly affect the NADP- dependent MDH activity in the liver PMC.

In our studies, for an integrated assessment of prooxidant/antioxidant balance changes in liver and blood of rats at $\mathrm{CeO}_{2}$ NPs or metformin action, the coefficient reliability ( $\mathrm{Kr}$ ) of the balance has been used, which is calculated according to the formula described in the section "Materials and Methods" with the data given in tables 1 and 2. In the absence of significant changes under the any influence, the coefficient would amount to $\sim 1$ c.u.

In our work, the calculated $\mathrm{Kr}$ value is 4.99 c.u. in rats received $\mathrm{CeO}_{2} \mathrm{NPs}$, while at metformin using -4.94 c.u. These data indicate that the reliability of prooxidant/antioxidant balance in response to the application of the $\mathrm{CeO}_{2} \mathrm{NPs}$ or metformin increases almost 5 times in comparison to the intact animals.

Based on the analysis of physiological (rectal temperature and $\mathrm{T}_{4}$ level) and biochemical parameters (the content of LPO products and the activity of enzymes of the glutathione-dependent antioxidant system), as well as based on the calculation of the reliability coefficient of the prooxidant/antioxidant balance, we can assume the geroprotective activity of NPs $\mathrm{CeO} 2$ and metformin in ageing rats.

The study of the survival of control and experimental rats was carried out from 670 days after birth to the end of the life of the last animal. Presented in Fig. 2 survival data, which were calculated by the Kaplan-Meier method, suggest that indicators of survival in experimental animals are significantly higher than in the control rats. The degree of slowing down of mortality in experimental animals is especially pronounced at the initial stages of the experiment. Thus, the survival rate of control rats was less than 0.9 conventional units by 730 days after birth, with the use of $\mathrm{CeO}_{2} \mathrm{NPs}$ - by 800 days, and with the use of metformin - by 810 days of the experiment (Fig. 2). Reduced survival rate lesser than 0.8 c.u. in the control rats is observed by 780 day after birth, and in experimental animals only to the 860 Day - for the received $\mathrm{CeO}_{2}$ group NPs, and by the 870 Day - for the group received metformin. Reduced survival rate less than 0.6 c.u. in the control is occurred by 850 days after birth, and in rats treated with $\mathrm{CeO}_{2}$ NPs - only by 920 days, for the metformin group -950 days. The median survival of animals was in control rats -900 days, animals receiving $\mathrm{CeO}_{2} \mathrm{NPs}-960$ days, in animals treated with metformin - 990 days. In the later stages of ontogeny, the effect of the $\mathrm{CeO}_{2} \mathrm{NPs}$ is less pronounced. So, the decrease in survival is less than $0.4 \mathrm{c}$. u. in the control animals occurred at 950 day, while the experimental animals treated with $\mathrm{CeO}_{2} \mathrm{NPs}$ - to 990 day, while metformin - at 1030 day. Survival decrease lesser than 0.2 c.u. in the control animals occurred at 1040 day; the experimental animals received $\mathrm{NPs}_{\mathrm{CeO}} \mathrm{Ce}_{2}$ to 1050 day, and metformin -1080 . 


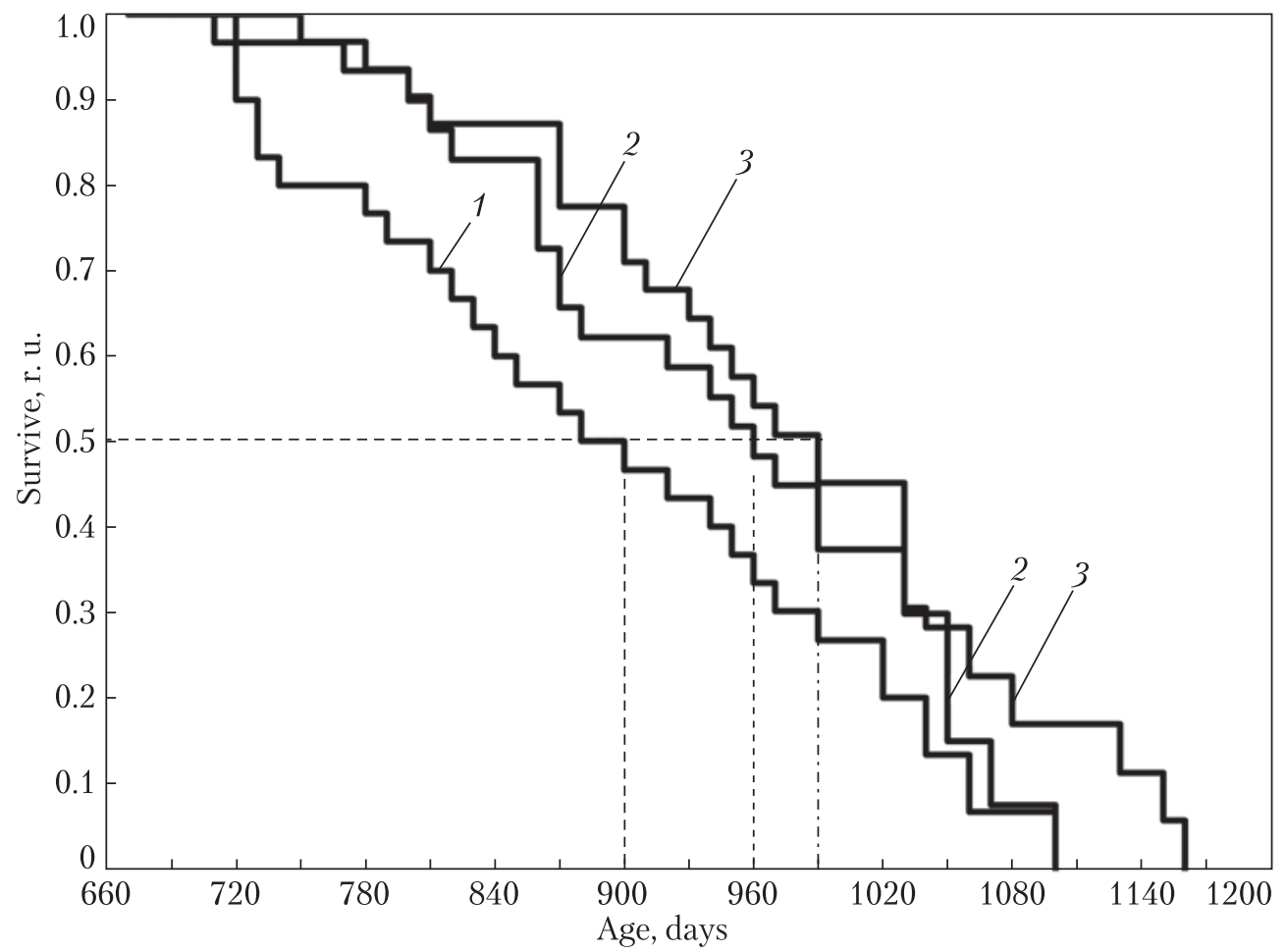

Fig. 2. Effect of a long-term use of $\mathrm{CeO}_{2}$ nanoparticles or metformin on the survival rate of old rats: 1 - control (- -); $2-\mathrm{CeO}_{2}$ nanoparticles ( $\left.\cdots \cdots\right) ; 3-$ metformin $\left(“--^{-*}\right)(n=30-31)$

Notes: Median of survival in control animals is 900 days; in rats received $\mathrm{CeO}_{2}$ nanoparticles -960 days, and in rats received metformin, -990 days.

Based on the analysis of survival curves, it should be noted that the action of $\mathrm{CeO}_{2} \mathrm{NPs}$, in the used concentration $(0.25-0.30 \mathrm{mg} / \mathrm{kg}$ body weight, with drinking water) is most effective only in the initial stage of the experiment.

CR-mimetic metformin affects the survival of experimental animals significantly greater than $\mathrm{CeO}_{2} \mathrm{NPs}$ at the initial stage of the experiment, and especially - in the later stages of the study.

The data obtained allow us to conclude about the prospects of the $\mathrm{CeO}_{2} \mathrm{NPs}$ and metformin for the development of geroprotector drugs, increasing the survival of ageing animals. However, taking into account certain contradictions about the effect of metformin on life expectancy [8], as well as data on its certain toxicity [9], from our point of view, cerium dioxide nanoparticles could be more promising to increase the reliability of prooxidant / antioxidant balance and the survival of aging rats.

Conclusions. Published earlier data on the beneficial effect of orthovanadate NPs during normal and accelerated ageing on physiological and biochemical indices of ageing organism $[12,14,15]$ are consistent with those of the present work on the possibility of a correction of agerelated changes and an increase in the survival of ageing animals with NPs. Accounting for the survival curves and the stabilizing effect of the investigated compounds on the prooxidant/antioxidant balance, we can conclude that they are promising for the development of geroprotective drugs that slow down the ageing process. 


\section{REFERENCES}

1. Masoro, E. J. (2000). Caloric restriction and aging: an update. Exp. Gerontol., 35, pp. 299-305. https://doi. org/10.1016/S0531-5565(00)00084-X

2. Yu, B. P., Lim, B. O. \& Sugano, M. (2002). Dietary restriction downregulates free radical and lipid peroxide production: plausible mechanism for elongation of life span. J. Nutr. Sci. Vitaminol. (Tokyo), 48, No. 4, pp. 257-264. https://doi.org/10.3177/jnsv.48.257

3. Merry, B. J. (2004). Oxidative stress and mitochondrial function with ageing - the effects of calorie restriction. Ageing Cell, 3, No. 1, pp. 7-12. https://doi.org/10.1046/j.1474-9728.2003.00074.x

4. Belostotskaia, L. I., Dziuba, V. N. \& Nikitchenko, I. (2008). The effect of three different hypocaloric diets on oxidative phosphorylation and activity of enzymatic antioxidant system in rat liver mitochondria. Advances in gerontology = Uspekhi gerontologii, 21, No. 2, pp. 235-239 (in Russian). https://europepmc.org/article/ med/18942367

5. Nikitchenko, Yu. V. (2012). Prooxidant-antioxidant system in ageing processes and experimental approaches to its correction (Extended abstract of Doctor thesis). V. Karasin National University, Kharkiv, Ukraine (in Russian).

6. Weindruch, R. (2006). Will dietary restriction work in primates? Biogerontology, 7, No. 3, pp. 169-171. https://doi.org/10.1007/s10522-006-9007-0

7. Anisimov, V. N. (2008). Molecular and physiological mechanisms of aging. St. Petersburg: Nauka.

8. Smith Jr, D. L., Elam Jr, C. F., Mattison, J. A., Lane, M. A., Roth, G. S., Ingram, D. K. \& Allison, D. B. (2010). Metformin supplementation and life span in Fischer-344 rats. J Gerontol. Biol. Sci., 65, No. 5, pp. 468-474. https://doi.org/10.1093/gerona/glq033

9. Wang, G. S. \& Hoyte, C. (2019). Review of Biguanide (Metformin) Toxicity. J Intensive Care Med., 34, No. 11-12, pp. 863-876. https://doi.org/10.1177/0885066618793385

10. DeCoteau, W., Heckman, K. L., Estevez, A. Y., Reed, K. J., Costanzo, W., Sandford, D. \& Parker, M. (2016). Cerium oxide nanoparticles with antioxidant properties ameliorate strength and prolong life in mouse model of amyotrophic lateral sclerosis. Nanomed.-Nanotechnol., 12, No. 8, pp. 2311-2320. https://doi.org/10.1016/j. nano.2016.06.009

11. Klochkov, V. K., Grigorova, A. V., Sedyh, O. O. \& Malyukin, Y. V. (2012). The influence of agglomeration of nanoparticles on their superoxide dismutase-mimetic activity. Colloids Surf. A Physicochem. Eng. Asp., 409, pp. 176-182. https://doi.org/10.1016/j.colsurfa.2012.06.019

12. Nikitchenko, Y. V., Klochkov, V. K., Kavok, N. S., Karpenko, N. A., Yefimova, S. L., Nikitchenko, I. V. \& Bozhkov, A. I. (2020). Age-related effects of orthovanadate nanoparticles involve activation of GSHdependent antioxidant system in liver mitochondria. Biol. Trace Elem. Res. https://doi.org/10.1007/s12011020-02196-7

13. Frolkis, V. V. \& Muradian, K. K. (1991). Life span prolongation. Boston-London: CRC Press.

14. Nikitchenko, Yu. V., Klochkov, V. K., Kavok, N. S., Karpenko, N. A., Sedych O. O., Bozhkov, A. I., Malyukin, Yu. V. \& Semynozhenko, V. P. (2020). Gadolinium orthovanadate nanoparticles increase survival of old rats. Dopov. Nac. akad. nauk Ukr., No. 2, pp. 29-36 (in Russian). https://doi.org/10.15407/dopovidi 2020.02 .029

15. Nikitchenko, Yu. V., Klochkov, V. K., Kavok, N. S., Karpenko, N. A., Sedyh, O. O., Bozhkov, A. I., Malyukin, Yu. V. \& Seminozhenko, V. P. (2020). Orthovanadate nanoparticles delay accelerated ageing in rats via prevention of oxidative disturbances. Dopov. Nac. akad. nauk. Ukr., No. 7, pp. 43-51. https://doi.org/10.15407/ dopovidi2020.07.043

Received 30.08.2020 
Ю.В. Нікітченко ${ }^{1}$, В.К. Клочков ${ }^{2}$, Н.С. Кавок ${ }^{2}$,

Н.О. Карпенко ${ }^{2}$, О.О. Сєдих ${ }^{2}$, I.В. Нікітченко, |

А.І. Божков ${ }^{1}$, С.Л. Сфімова ${ }^{2}$, В.П. Семіноженко ${ }^{2}$

${ }^{1}$ Харківський національний університет ім. В.Н. Каразіна

${ }^{2}$ Інститут сцинтиляційних матеріалів, НТК “ІМК” НАН України, Харків

E-mail: kavok@isma.kharkov.ua

\section{НАНОЧАСТИНКИ ДІОКСИДУ ЦЕРІЮ ТА МЕТФОРМІН ПІДВИЩУЮТЬ НАДІЙНІСТЬ ПРООКСИДАНТНО/ АНТИОКСИДАНТНОГО БАЛАНСУ ТА ЗБІЛЬШУЮТЬ |ВИЖИВАНІСТЬ ЩУРІВ, ЩО СТАРІЮТЬ}

У порівнянні з дією метформіну - міметика низькокалорійної дієти, що продовжує життя тварин, вивчається вплив наночастинок діоксиду церію $\left(\mathrm{CeO}_{2} \mathrm{HЧ} \mathrm{(1-2} \mathrm{нм))} \mathrm{на} \mathrm{виживання,} \mathrm{фізіологічні} \mathrm{показ-}\right.$ ники (концентрація тироксину, ректальна температура) та біохімічні показники (вміст ліпідних гідропероксидів, активність ферментів аконітази, глутатіонпероксидази, глутаредоксину, глутатіонредуктази, НАД $\Phi^{+}$-дегідрогеназ (глюкозо-6-фосфат дегідрогеназа, малат дегідрогеназа та ізоцитрат дегідрогеназа) у сироватці крові, мітохондріальної та постмітохондріальної фракцій печінки.

Було встановлено, що тривале використання $\mathrm{CeO}_{2} \mathrm{HЧ} 3$ питною водою (0,25-0,30 мг / кг маси тіла на добу) або метформіну (100-110 мг / кг маси тіла на добу) з 670 днів після народження призводило до значного збільшення виживання (медіана виживаності контрольних щурів становила 900 днів, у тварин, які отримували $\mathrm{CeO}_{2} \mathrm{HЧ}-960$ днів, і метформіну - 990 днів), зниження ректальної температури, уповільнення зниження тироксину в крові та нормалізації прооксидантно/антиоксидантного балансу в тканинах печінки та крові. Розрахований інтегральний показник надійності прооксидантно/антиоксидантного балансу (коефіцієнт надійності) у досліджуваних тканинах щурів у відповідь на використання $\mathrm{CeO}_{2}$ НЧ зріс в 4,99 раза, а метформіну - у 4,94 раза порівняно з інтактними тваринами.

Отримані дані дозволяють зробити висновки щодо перспектив наночастинок $\mathrm{CeO}_{2}$, а також метформіну для розробки геропротекторних препаратів, що сприяють поліпшенню здоров’я та збільшують виживаність організму при старінні.

Ключові слова: наночастинки $\mathrm{CeO}_{2}$, метформін, прооксидантно/антиоксидантний баланс, тироксин, температура тіла, печінка, кров, виживання старих щурів-самців. 